\title{
Redaksjonelt
}

\section{Nye artikler våren 2015}

Acta Didactica Norge er et nasjonalt tidsskrift for fagdidaktisk forsking. Med oppstart alt i 2007 er det det eldste open-access-tidsskriftet ved Universitetet i Oslo. I begynnelsen ble det driftet av Institutt for lærerutdanning og skoleforskning, men i mars 2015 ble tidsskriftet flyttet til Universitetet i Oslos FRITT-server. Universitetet i Oslos satsing på open-access-publisering via denne serveren har gitt forbedringer i den daglige driften, ikke minst for indekseringen av våre artikler, nasjonalt og internasjonalt.

Også i 2015 opplever Acta Didactica Norge god tilgang på artikler på mange forskjellige fagområder. Vårens utgave har artikler skrevet på bokmål, nynorsk, dansk, svensk og engelsk. Stadig flere stipendiater som skriver artikkelbaserte, fagdidaktiske doktoravhandlinger, velger også å sende inn sine artikler til oss.

I årets første artikkel, "Verdsetting av brukermedvirkning ved utforming av skoleanlegg", undersøker Else Margrethe Lefdal hvordan skolens brukere, deriblant lærere, får delta i utformingen av nye skolebygg. Hun tolker dagens "[o]mfattende bruk av innvendig glass i skoleanlegget [. . .] som et kompromiss mellom skoleeiers ønske om åpenhet og kontroll, lærernes ønske om mindre støy og arkitektens ønske om å skape romfølelse og visuelle siktlinjer”. Den neste artikkelen, Toril Aagaards "Når teknologi møter fagtradisjoner i norsk og mediefag på videregående skole”, sammenlignes norsk- og medielæreres erfaringer og tanker omkring undervisning i teknologitette omgivelser. Det kan nevnes at denne var den tredje og siste artikkelen i hennes doktoravhandling, som hun forsvarte den 28/6 2015. I årets tredje artikkel undersøker Raymond Bjuland, Nina Helgevold og Elaine Munthe bruken av Lesson Study i naturfag og matematikk i lærerutdanningen. Deres analyser av "veiledningssamtaler fra to studentgrupper tilknyttet naturfag og matematikk" viser store forskjeller med tanke på gruppenes planlegging av undervisningen. De påpeker at det er "behov for et grundig forarbeid på campus av faglærere ved utdanningsinstitusjonen slik at studentene får muligheten til å forberede en Lesson Study syklus” og løfter også frem behovet "for et godt samarbeid mellom faglærere og praksislærere ved skolene" som en forutsetning for en vellykket implementering.

To av vårens artikler handler om skriving og skriveundervisning. I den ene, "Summativ vurdering i formativ drakt - elevperspektiv på tilbakemelding fra heldagsprøver i norsk", analyserer Agnete Bueie “[. . .] hvordan elever på ungdomstrinnet forstår og bruker skriftlige lærerkommentarer på heldagsprøvebesvarelser i norsk". Hun konkluderer med at bedre tilrettelegging vil kunne hjelpe elevene til å bruke kommentarene mer aktivt, og dermed gi 
heldagsprøven en sterkere formativ funksjon. Den andre artikkelen, May Horveraks "English writing instruction in Norwegian upper secondary schools", presenterer en studie av skriveundervisningen i engelskfaget på Vg1. Hun finner at "engelsklærere fokuserer på å undervise sjangerkrav og det å tilpasse språk til oppgave og kontekst”. På samme tid viser det seg at de er noe usikre på hvordan man skal undervise i ulike teksttyper, og i hvordan man kan tilpasse teksten til oppgaven og situasjonen. Hun konkluderer med at det er "behov for å forbedre engelsklærerutdanningen når det gjelder opplæring i skriveundervisning”.

I denne utgaven kan vi også presentere to artikler om litteraturdidaktikk. I "Jeg har forstået den sådan, at den ikke skal forstås" - når 6A læser Franz Kafka” drøfter Martin Blok Johansen en problemstilling som de aller fleste språklærere står overfor: utvalget av litterære tekster til undervisningen. Han hevder, på tvers av dagens tendens til å vektlegge barns interesser når man velger ut litterære tekster, "at litteratur for børn ikke nødvendigvis skal tilgodese børns interesser og umiddelbare lyst, men indimellem også være litteratur". Vårens andre artikkel om litteraturundervisning er Catarina Economous "Litteraturarbete i ett svenska som andraspråksklassrum". Hun undersøker "hur en grupp avancerade andraspråksinlärare i en svensk gymnasieskola läser, tolkar och diskuterar en modern svensk roman och hur de interagerar med texten och med varandra i relation till texten". Economou konkluderer at litteraturundervisning og arbeid med litteratur kan " bli ett medel för personlighetsutveckling liksom för språkutveckling” og ikke minst bidra til "meningsfulla samtal mellan elever från olika bakgrund".

I den historiedidaktiske artikkelen "The Norwegian curriculum in History and Historical thinking: A case study of three lower secondary schools" finner Lisbeth Bergum Johanson at "historieundervisningen fortsatt er forholdsvis tradisjonell i den forstand at lærebøker i historie anvendes ukritisk, uten å problematisere hvordan historie konstrueres eller hvorfor historie er viktig både i dag og for fremtida”. Hun foreslår å dreie vektleggingen i undervisningen fra reproduksjon til refleksjon, og at "både lærere og elever jobber mer med historisk tenkning”. Reidar Mosvold og Janne Fauskangers matematikkdidaktiske artikkel, "Kartlegging av læreres kunnskap er ikke enkelt”, handler om måling av læreres kunnskaper, i dette tilfellet i matematikk. Deres studie viser at slike målinger må foretas med stor forsiktighet, og at det trenges mer forskning for å finne ut "hva slags type kunnskap som kan måles med ulike typer oppgaver, og hva slags måleinstrumenter som kan brukes”. Deretter tar Inger Auestad opp et evigaktuelt emne i norsk skole, nemlig tilpasset opplæring. Hennes artikkel, "Fellesskap i oppløysing? Differensieringspraksis på 6. trinn”, problematiserer i stor grad dagens praksis. Hun viser eksempler på at differensieringstiltak "som på den eine sida skal støtte læringa og gi elevar tilpassa opplæring, fører til tap av meining og færre mulegheiter for deltaking i fellesundervisninga for elevar som blir vurderte til å vera svake”. 
Vårens siste artikkel er på et helt annet område, idrettsdidaktikk. André Horgens "Educational expeditions - et norsk perspektiv", som handler om friluftsliv brukt pedagogisk med tanke på personlig utvikling. Horgen tar utgangspunkt i "britisk og angloamerikansk tradisjon og stiller spørsmål vedrørende temaet personlig utvikling i norsk friluftslivspedagogisk tradisjon”. Han undersøker om og i hvor stor grad "norske bachelorstudenter i friluftsliv opplever at de lærer [...] noe om sin egen person og sine leder/veilederegenskaper under lange ferder i vinterfjellet”.

For tiden er en rekke artikler i prosess til høstens utgave, og de innsendte artiklene tyder på at det også her kan bli mange interessante artikler om mange ulike emner. Det arbeides også med to temanummer, som etter planen skal komme ut i 2016. Den første utgaven vil være et temanummer med en rekke artikler om lærerutdanning, et felt som vies stadig større interesse. Det andre temanummeret vil handle om skoleledelse. Et stort antall forfattere har vist sin interesse og er i gang med skrivingen.

Redaksjonen vil poengtere at det i tillegg til temaartiklene også vil være rom for "vanlige” artikler. Vi vil med dette ønske våre lesere, fagfellevurderere og forfattere en god sommer.

Oslo, 10 Juni 2015

Glenn Ole Hellekjær

Ansvarlig redaktør 